\title{
To Restore or Not to Restore: Assessing Pre-project Conditions of a Habitat Restoration Project on the New River, North Carolina
}

\author{
Bobbie Swinson $^{1} \cdot$ Kristan Cockerill $^{2} \cdot$ Jeffrey Colby $^{1}$ • \\ Shea Tuberty ${ }^{3} \cdot$ Chuanhui Gu$^{4}$
}

Received: 27 February 2015 / Accepted: 31 August 2015 / Published online: 14 September 2015

(C) Springer International Publishing Switzerland 2015

\begin{abstract}
Despite continued emphasis on restoring streams to improve ecological function, there remains a dearth of data documenting pre-restoration conditions to clearly establish a need for restoration. Without establishing a clear, data-driven need for restoration, it is difficult to determine which restoration measures will be most effective. The study reported here offers a pre-project evaluation of a restoration on a headwaters stream in the Appalachian Mountains of North Carolina, USA. The authors conducted in-depth interviews with project sponsors, and reviewed the project environmental assessment and construction plans. Additionally, the authors evaluated available data, including benthic macroinvertebrate assemblages, fish communities, riverbed coarse particle size, and ambient water quality. Primary goals for the restoration project include halting erosion and improving aquatic habitat. The data that were used to justify the restoration and develop the environmental assessment and project plan, however, present temporal and spatial issues that may preclude effective evaluation of the need for the project and conducting valid post-project assessments. Available data reveal that current
\end{abstract}

Bobbie Swinson

swinsonbj@appstate.edu

Kristan Cockerill

cockerillkm@appstate.edu

Jeffrey Colby

colbyj@appstate.edu

Shea Tuberty

tubertysr@appstate.edu

Chuanhui $\mathrm{Gu}$

guc@appstate.edu

1 Department of Geography and Planning, Appalachian State University, Boone, NC 28607, USA

2 Department of Cultural, Gender and Global Studies, Appalachian State University, Boone, NC 28607, USA

3 Department of Biology, Appalachian State University, Boone, NC 28607, USA

4 Department of Geology, Appalachian State University, Boone, NC 28607, USA 
conditions are quite good and potentially do not warrant ecological restoration measures. Over a longer temporal scale, this project may be limited in the ability to improve conditions or prevent degradation because of concentrated anthropogenic activities occurring upstream within the watershed as well as adjacent to the restored reach.

Keywords Stream restoration $\cdot$ River management $\cdot$ Benthic macroinvertebrate $\cdot$ Fish community · Water quality

\section{Introduction}

Stream restoration projects intended to enhance water quality, improve in-stream habitat, and stabilize eroding banks have become a multi-billion dollar a year industry (Bernhardt et al. 2005). Despite the popularity of stream restoration, the evidence is decidedly mixed on the effectiveness of many ecological restoration efforts. There is a growing body of literature reporting underwhelming results for projects that have been evaluated (Shields et al. 2003; Sudduth et al. 2007; Alexander and Allan 2007; Cabin 2007; O'Donnel and Galat 2008; Palmer et al. 2010; Bernhardt and Palmer 2011; Violin et al. 2011; Cockerill and Anderson 2014). Hypothesized causes for the negative results include the opportunistic nature of projects, which are frequently of small-scale and occur where there are agreeable landowners and funding rather than where data suggest projects would have the most beneficial impact (Bernhardt et al. 2007; Palmer and Allan 2006; Alexander and Allan 2007; Kondolf et al. 2007; Christian-Smith and Merenlender 2010; Cockerill and Anderson 2014); and a lack of communication between researchers and restoration practitioners (Rhoads et al. 1999; Wohl et al. 2005; Wheaton et al. 2006; Cockerill and Anderson 2014). One result from the lack of communication between practitioners and researchers is that historic and/or contemporary geomorphological, ecologic, and hydrologic conditions are often not fully assessed or understood prior to restoration project implementation and this likely contributes to project failure (Kondolf et al. 2001; Moerke and Lamberti 2003; Niezgoda and Johnson 2005; Smith and Prestegaard 2005; WoelfleErskine et al. 2012). This lack of attention to physical and biological conditions prior to implementing a restoration project begs the question of whether restoration is really needed and how it is determined if or how a stream would benefit from restoration.

Throughout the stream restoration literature, there are frequent references to the general state of stream degradation in the US as motivating and/or justifying restoration. Interviews with project managers reveal that "environmental degradation" is what motivates most restoration efforts and water quality management is the primary goal for most projects (Hassett et al. 2007; Bernhardt et al. 2007; Sudduth et al. 2007). What is not as clear from the literature is precisely how environmental degradation at a specific location is determined or documented. Project managers report that previous experience and government agency reports or documents are the sources most commonly used to design a restoration project (Hassett et al. 2007; Bernhardt et al. 2007; Sudduth et al. 2007). In many cases, a reference stream is used as a guide, but assessments of this practice find it problematic and suggest it is better to identify specific objectives for a project (Dufour and Piegay 2009; Downs et al. 2011). Objective driven projects require collecting baseline data, which is not often done (Hassett et al. 2007; Downs et al. 2011). 
In this paper, the authors apply an interdisciplinary approach to evaluate the preimplementation conditions for a $\$ 2.6$ million aquatic habitat restoration project at a public greenway in Boone, North Carolina. The authors gathered data on the water quality and biological conditions at the site to be restored, and integrated this with data from interviews with the project sponsors and from the pre-project environmental assessment and construction documents.

This study focused on answering the following questions:

1. What is the motivation for and the expected outcomes from this restoration and on what are these based?

2. Do available data suggest a need for restoration?

3. How do the project sponsors plan to monitor the effects of restoration measures?

\section{Background}

\subsection{Study Area}

The restoration site is located at the outlet of the Upper South Fork New River (USFNR) watershed, which represents the headwaters of the South Fork of the New River in Watauga County in western North Carolina (Fig. 1). The USFNR watershed $\left(80 \mathrm{~km}^{2}\right)$ encompasses the towns of Boone and Blowing Rock and is unique as it includes pristine reaches (e.g., supporting native brook trout populations), with three reaches currently listed as impaired, and an expanding urban environment.

Boone is home to about 17,000 full time residents (U.S. Census Bureau 2010) and is also home to Appalachian State University (ASU), which enrolls about 17,000 students (Institutional Research Assessment and Planning 2013). Watauga County experienced a twenty percent growth rate between 2000 and 2010 (U.S. Census Bureau 2010).

The Town of Boone Greenway is located in one of the few relatively flat areas within the USFNR watershed. The restoration site encompasses a $1137 \mathrm{~m}$ reach along with approximately six hectares of floodplain. The adjacent topography largely confines the river, and the floodplain is approximately $300 \mathrm{~m}$ wide in the upstream portion of the reach then narrows to about $30 \mathrm{~m}$ downstream where two valley walls converge. The channel gradient has an average slope of $0.00133 \mathrm{~m} / \mathrm{m}$, and the bed material is predominately sands and gravels, with some cobbles, and small areas of exposed bedrock (United States Army Corps of Engineers [USACE] 2009).

Four distinct habitats are found in the study area and include riverine, riparian, forestland, and manicured urban grassland as the dominant habitat type (USACE 2009). ASU athletic fields border the left overbank (river left - facing downstream) for the majority of the upper reach, with forest bordering the entire left bank of the lower reach of the restoration site. A paved trail borders the right overbank (river right) of the entire reach and is managed by the Town of Boone. ASU athletic fields and open space are located in the middle of the site in the area between the upper and lower reach.

\subsection{Restoration Project}

The restoration project partners are: the USACE; the Town of Boone, North Carolina; the New River Conservancy (NRC); and ASU. The project is authorized by Congress under 


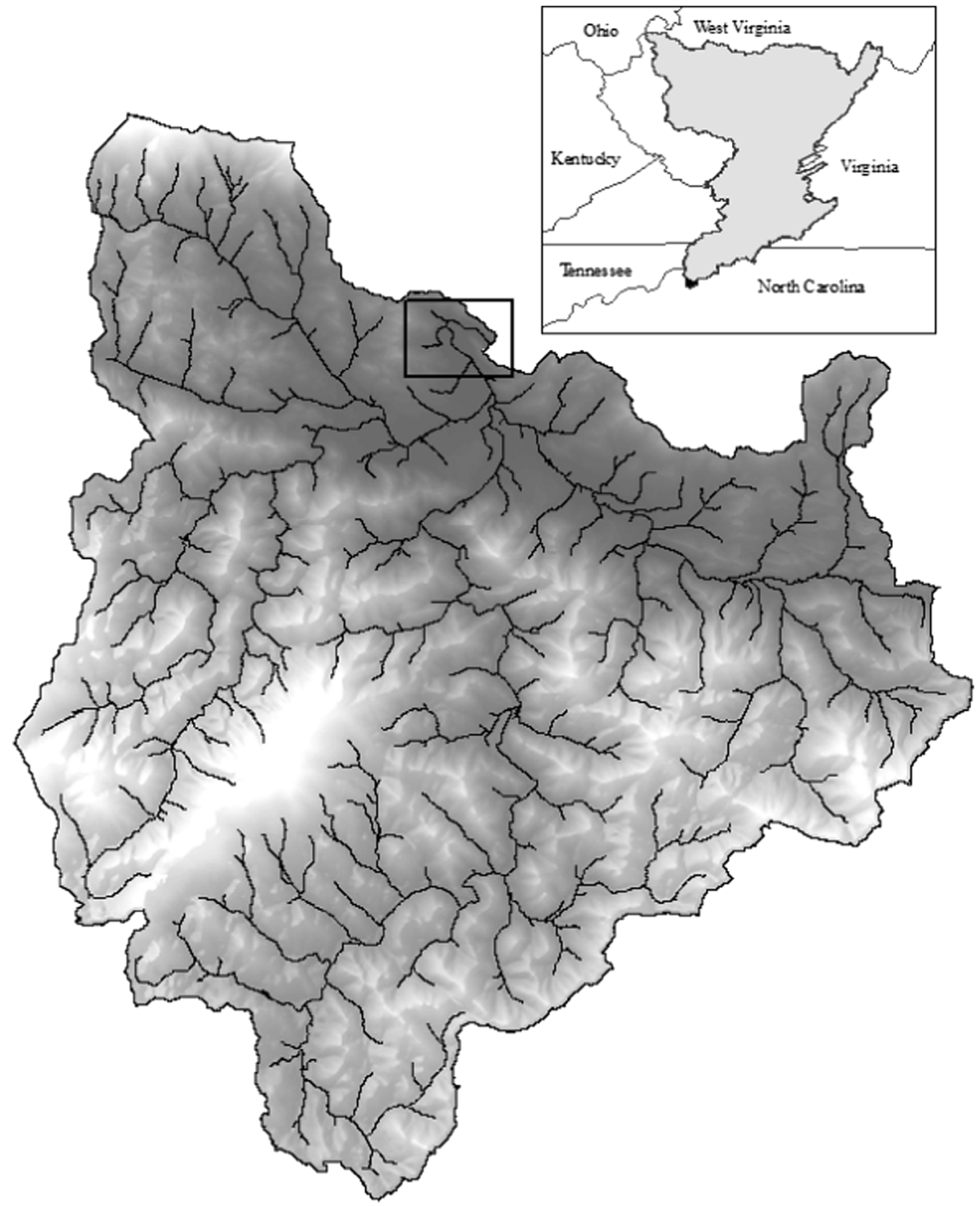

Fig. 1 Study area. The location of the restoration project (solid rectangle) is at the outlet of the Upper South Fork New River watershed, which represents the headwaters of the South Fork of the New River in Boone, North Carolina. The South Fork is a tributary of the New River, and part of the Ohio River drainage basin

Section 206 Water Resources Development Act, which gives USACE authority to carry out aquatic restoration projects that will improve the quality of the environment, are in the public interest, and are cost-effective (Water Resources Development Act 1996). A request from a public agency or national non-profit organization initiates the Section 206 process; in the case documented here, the Town of Boone made such a request in 1998. In response, the USACE Huntington District conducted a feasibility study to determine whether the project was in the federal interest and would be cost effective. This study formulated alternatives (including a no 
action alternative), evaluated the environmental effects of the alternatives, documented the project requirements, and provided a project cost estimate.

Once authorized, USACE prepared detailed project plans, obtained necessary federal permits and will oversee construction. Section 206 projects require cost sharing between USACE (65\%) and the local sponsor (35\%) for implementation, and the local sponsor is responsible for all post-implementation operation and maintenance costs (Water Resources Development Act 1996). As the local sponsor, the Town of Boone partnered with a local land conservation organization, The New River Conservancy, for funding acquisition. The NRC will hold a permanent conservation easement on the riparian area after project completion. ASU owns much of the property adjacent to the restoration project, and therefore, their cooperation was integral to developing a project plan.

\section{Methods}

Interviews with project sponsors were undertaken to understand the motivations and expected outcomes of the project, and how these aligned with available data and with the project environmental assessment and construction plans. Ecological data were reviewed in an attempt to identify a need for restoration. This included the data used to develop the project environmental assessment as well as fish, benthic macroinvertebrate, riverbed coarse particle assessments, and water quality data collected by the Appalachian Aquatic Science Research Group (AppAqua) at Appalachian State University.

\subsection{Interviews}

The lead author conducted interviews with the primary project sponsors, USACE, the Town of Boone, and NRC to understand the planning and design process and to assess how well the project design aligned with the data used and the stated motivation for the restoration project (interview questions in Table 1). The interview with USACE included the lead engineer, lead planner, and the lead real estate specialist for the project. The Executive Director of NRC was interviewed as well as the restoration project manager for the Town of Boone. Additionally, an engineer from the ASU Office of Planning, Design, and Construction met with the lead author and reviewed the plans for changes being made to the athletic fields adjacent to the project area.

The interviews were all recorded and written notes were also taken. Immediately following each interview the notes were reviewed and expanded as appropriate using the recordings to

Table 1 Questions asked during interviews with restoration project sponsors: the United States Army Corps of Engineers, New River Conservancy, and the Town of Boone
Project sponsor interview questions

Who proposed the project?

When did planning begin?

How is the project being funded and what is the budget?

Why is the project important?

What are the objectives and expected outcomes?

What data is being used to guide planning and design?

How will success be determined? 
add details or clarify points. The lead and second author independently coded the notes. The coding matrix included four themes: project motivation, expected outcomes, data used for planning and design, and monitoring plan for evaluating restoration efficacy. The two sets of coded material were compared for consistency and in the few places where information had not been coded similarly, the recordings and/or original notes were revisited and the coding was aligned as appropriate.

\subsection{Detailed Project Report and Environmental Assessment}

USACE provided the Detailed Project Report and Final Environmental Assessment (henceforth EA), completed in 2009, as well as the December 2013 draft construction plans for the project. These documents were examined and compared with interview results to assess how well management objectives and expected outcomes aligned with available data and project planning. The EA included information and data used to characterize the project site as well as the overall plan for the restoration site.

\subsection{Biological and Water Quality Data Review}

The EA included summary ecological and water quality data collected by USACE and the North Carolina Department of Environment and Natural Resources (NCDENR) from1998 through 2008. Biologic data included: electrofishing survey results from 2004 (USACE); benthic macroinvertebrate data collected by North Carolina's basinwide monitoring program in 2003 and 2008 (NCDENR); and water quality data from the NCDENR ambient monitoring system (AMS) from 1998 through 2003 (Table 2).

The data used to develop the EA were limited in both temporal range and geographic location. The EA was drafted in 2009, yet only reported NCDENR AMS data through 2003. In addition, NCDENR benthic macroinvertebrate monitoring stations and AMS stations are located outside the boundaries of the project reach.

As part of an on-going effort to study land cover and water quality relationships in the USFNR watershed, the AppAqua research team has collected diverse data within the restoration project reach (Table 2). Relevant to this study, AppAqua has electrofishing and benthic macroinvertebrate surveys from 2013, riverbed coarse particle size data from 2013 to 2014,

Table 2 Biological, physical, and water quality data sources, collection site location, and collection period by data type

Biological and water quality data sources

\begin{tabular}{llll}
\hline Data type & Data sources & Collection site & Collection period \\
\hline Benthic macroinvertebrate & NCDENR & Outside restoration reach & 1993-2008 \\
& AppAqua & Within restoration reach & 2013 \\
Fish community & USACE & Within restoration reach & 2004 \\
\multirow{2}{*}{ Water quality } & AppAqua & Within restoration reach & 2013 \\
& NCDENR & Outside restoration reach & $1998-2003$ \\
Riverbed course particle size & AppAqua & Within restoration reach & 2013-2014 \\
& AppAqua & Within restoration reach & 2013-2014 \\
\hline
\end{tabular}


and water quality measurements (temperature, $\mathrm{pH}$, and conductivity) collected every $15 \mathrm{~min}$ at the upper and lower bounds of the restoration project reach since October 2013.

\subsubsection{Biological Assessment}

NCDENR Index of Biological Integrity NCDENR evaluates river water quality using biological assemblages, which includes fish and benthic macroinvertebrate communities. Criteria have been developed for assigning a North Carolina Index of Biological Integrity (NCIBI) rating for the three major ecoregions within the state: the mountains, piedmont, and coastal plain. Ratings are used to assess the impacts of both point and nonpoint source pollution.

Criteria for assigning NCIBI ratings have been developed using diversity, abundance, and pollution sensitivity of benthic macroinvertebrates (North Carolina Department of Environment and Natural Resources [NCDENR] 2012). One of five classifications are assigned to each water body sampled: Excellent, Good, Good-Fair, Fair or Poor.

Two primary macroinvertebrate collection methods are used. The first is a standard qualitative method (SQM), which can be used to assign water quality ratings to most wadeable streams and rivers in North Carolina. The second collection method is an abbreviated version of the regular qualitative technique that focuses on a subset of the sensitive benthic community, and is called the Ephemeroptera, Plecoptera, and Trichoptera method (EPT) (NCDENR 2012).

The NCIBI for the Stream Fish Community Assessment Program incorporates information about species richness and composition, pollution indicator species, trophic composition, fish abundance, fish condition, and reproductive function via a cumulative assessment of 12 parameters. The scores for all metrics are then summed to obtain the overall NCIBI score, which is then used to determine the biological integrity class of the stream (i.e., Excellent, Good, Good-Fair, Fair, or Poor) (NCDENR 2013).

Benthic Macroinvertebrate Assessment Two NCDENR benthic macroinvertebrate monitoring sites (KB1 and KB12) used to develop the EA are located approximately $650 \mathrm{~m}$ upstream from the restoration area on the Middle Fork and the East Fork, both tributaries of the South Fork of the New River. The third monitoring site (KB16/K2100000), carrying the longest data record, is located approximately $2.6 \mathrm{~km}$ downstream of the project area on the South Fork New River (Fig. 2). All samples on the Middle Fork and East Fork streams were assessed by NCDENR using the EPT method, while the South Fork site (KB16) has historically been assessed using the full SQM (NCDENR 2012).

AppAqua researchers collected and analyzed macroinvertebrate populations within the study area in April of 2013. The restoration reach was divided into three sections based on the geomorphic characteristics of the channel. The two large bends in the river create a distinct upper, middle and lower reach, which was conducive to sampling and analysis of macroinvertebrate populations from similar riffle habitats (Fig. 2).

The samples were collected in the riffle habitats using kick seines, rock washes and submerged woody debris searches. Data were analyzed and assigned NCIBI ratings according to a modified protocol of the NCDENR SQM (NCDENR 2012). This modification differs from the SQM only in that insects were identified to family rather than genus and species, and were assigned average sensitivity values determined from all members of the respective families. 


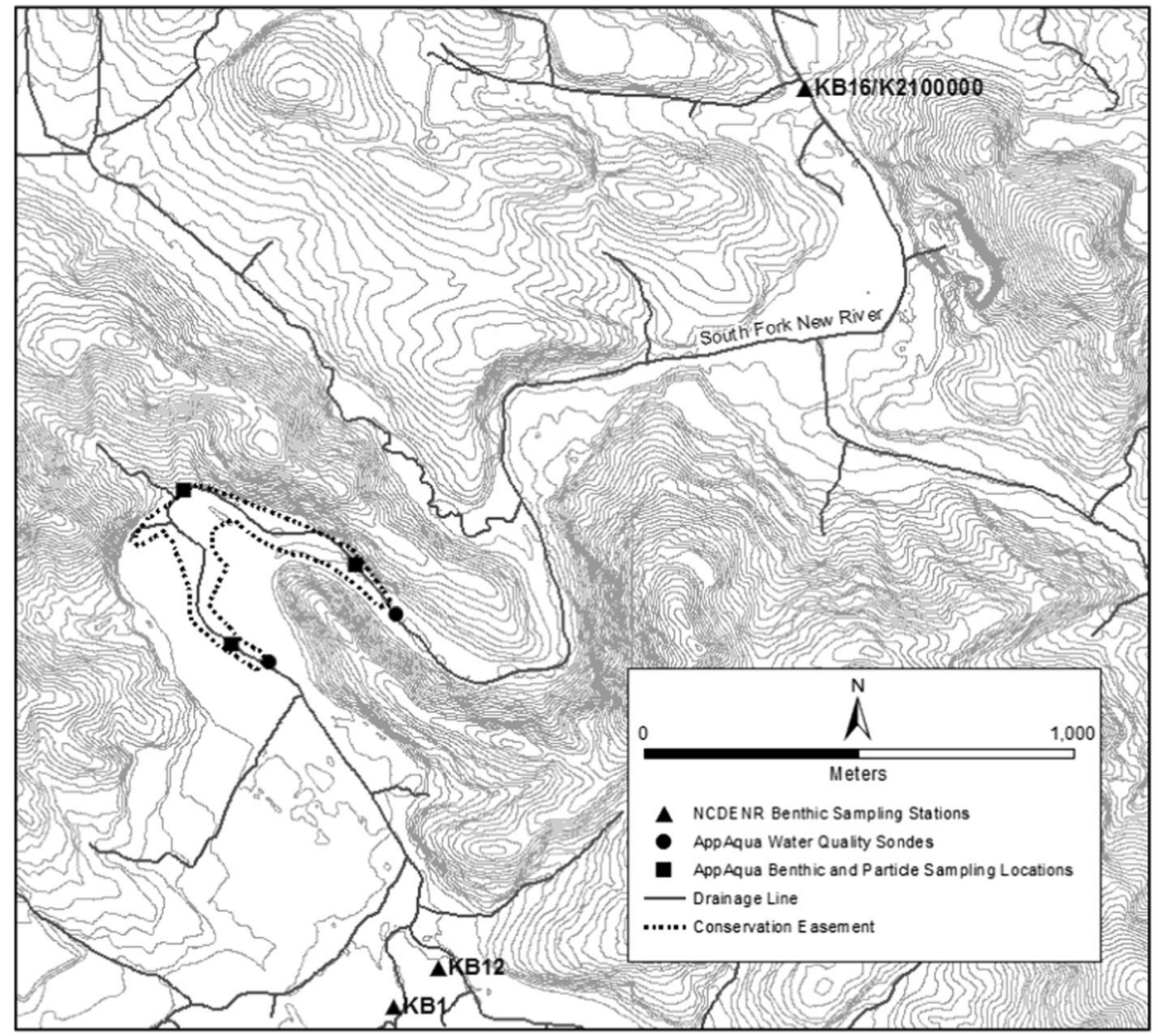

Fig. 2 Monitoring stations. North Carolina Department of Environment and Natural Resources benthic monitoring stations located upstream and downstream of the restoration reach. Station KB16 also serves as NCDENR ambient water quality monitoring station K2100000. AppAqua benthic, sediment, and water quality sonde locations within the restoration reach

Fish Community Assessment USACE undertook a comprehensive electrofishing survey to analyze fish communities within the project reach in 2004. An electric seine electrofishing unit with $9 \mathrm{~m}$ wires was used to collect fish samples from four $150 \mathrm{~m}$ sections along the $1137 \mathrm{~m}$ reach. Surveys were classified according to the North Carolina Index of Biological Integrity (NCIBI) for mountains of the New River drainage (NCDENR 2013), and the results were then used for developing the EA.

AppAqua researchers conducted an electrofishing survey within the project reach in March of 2013. Three backpack electrofishing units (Smith-Root, Inc.) were used to collect fish samples from a single pass through a $100 \mathrm{~m}$ reach of the middle section of the restoration area and the fish assemblage classified as above using the NCIBI methodology.

\subsubsection{AppAqua Riverbed Coarse Particle Size Assessment}

Each of three reaches (upper, middle, lower) of the restoration area were assessed for riverbed coarse particle size by AppAqua researchers using a gravelometer (Wildco) with 14 square 
holes of common sieve sizes (1/2-phi unit classes) ranging from 2 to $300 \mathrm{~mm}$. One hundred meter reaches of stream were divided into $10 \mathrm{~m}$ intervals using a tape measure. Ten particles were collected at random in each of the 10 intervals by walking in the stream and stopping at random to blindly pick up the particle closest to the big toe of the right foot. The data was organized by coarse particle size frequency and cumulative frequency distributions in Microsoft Excel 2010 using a modification of the methods recommended by Wolman (1954). An additional measure was employed to determine the median particle class size $\left(D_{50}\right)$ of the collected particles when distributions were arranged from smallest to largest. This allowed the determination of a single size class value for spatial and temporal comparison of particle sizes.

\subsubsection{Water Quality Assessment}

Data from the NCDENR AMS station located in the same geographic location as benthic station KB16 (Fig. 2) were used to draft the EA in 2009. Dissolved oxygen, specific conductivity, $\mathrm{pH}$, total suspended solids, turbidity, and nutrient data collected via grab samples were reported in the EA in the form of minimum, median, and maximum values from 1998 through 2003.

To further assess pre-restoration conditions of the project area, data collected by AppAqua sondes located upstream and downstream of the project reach were included in our assessment. Temperature, $\mathrm{pH}$, and specific conductivity data were examined and summarized in the form of minimum, median, and maximum values for October 2013 through July 2014.

\section{Results}

\subsection{Interviews}

Interviews with project sponsors revealed consistency in perceptions about the motivation, goals, expected outcomes, and monitoring plan for the restoration project (Table 3). The anomaly lies with ASU, which as a property owner is necessarily engaged with the project, but has unique interests and expectations. Additionally, across all the sponsors there were some differences in perceptions regarding if and how the project will be monitored.

\subsubsection{Project Motivation and Importance}

The lead engineer for the project at USACE said that when he first visited the site, he thought that it was a "Grade A-/B+ stream in good shape," but that ASU expansion and parking lots were a concern. He and other USACE interviewees noted that bank erosion (slumping and undercutting) was causing increased sedimentation throughout the reach, which was then "killing benthic macroinvertebrates," and the project will provide habitat improvements and stabilize the banks. In addition, interviewees said that recreational benefits (e.g., river access and greenway protection) are a vital part of the project.

The interview with NRC revealed that stabilizing the streambanks to stop the "unbelievable erosion" was the main motivation for the project. By stopping the erosion, NRC representatives said that they hope to reduce sedimentation and hence improve aquatic habitat. In addition, NRC suggested that the project is important for reconnecting the floodplain and 


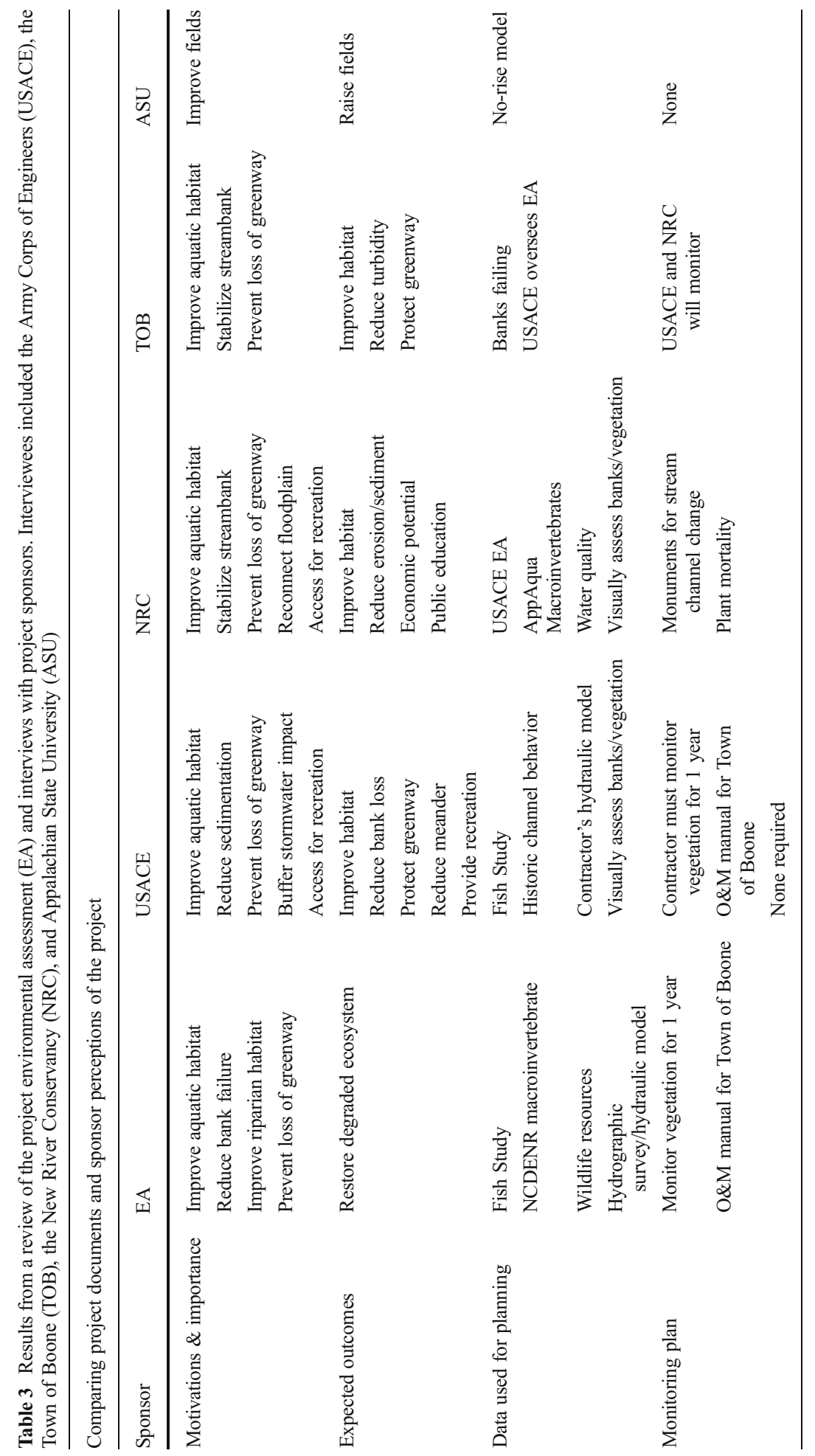


providing access to the river as well as increasing NRC's visibility. The Town of Boone said that the project is important for improving aquatic habitat, reducing turbidity, and protecting the recreational fields. The project manager for Boone indicated that the banks are falling into the river and that this is the primary issue that must be addressed. He said that there is a need for more upstream projects, but that the Town is not currently planning any. The ASU engineer said that this project was important because ASU is able to "piggyback" on the restoration efforts to gain fill material to improve conditions on the athletic fields.

\subsubsection{Expected Outcomes}

The USACE engineer said that he is expecting to reduce the river's meandering and "fix" bank stability issues within the river reach. This stabilization is expected to improve the habitat corridor and increase diversity while providing increased recreational opportunities and protecting the greenway. The engineer also mentioned that trout stocking was potentially an option but that this is a controversial topic and is not part of the restoration project.

The NRC Executive Director said that habitat improvement by reducing sediment could "serve an economic purpose," as the potential to stock the river with trout has been discussed but is not being pursued at this time. Additionally, he said that NRC "is not striving for a pristine river course," and that a "bunch of non-ideal projects could be better than one ideal project." He noted that the project has the potential to enhance educational outreach in the community and influence behavior on private property.

The project manager for the Town of Boone said that the project partners "all have the same goals: improve habitat, lower turbidity, and protect the recreational fields." The ASU engineer said that the university is able to utilize the spoil from bank excavation to raise the fields. Raising the fields approximately $15 \mathrm{~cm}$ is expected to help with flooding issues and generally improve the athletic fields.

\subsubsection{Data Used for Planning and Design}

USACE, along with NCDENR, performed the 2004 fish survey, however, other ecological data from other sources was simply summarized within the EA. This included macroinvertebrate data, water quality, and wildlife documented within the area. USACE acknowledged that it does not have good on-site geomorphic survey data within the project reach due to changing conditions and difficulties with environmental data collection. The engineer revealed that USACE used "assumptions of historic channel behavior" to plan the project. The engineer also acknowledged that often engineering decisions are made "on the fly" during construction.

The NRC Executive Director said that he relies on USACE to carry out the environmental assessment. However, he said that NRC assessed where stream banks were slumping, vegetation was lacking, and "where pressure points undermine the bank." In addition, he mentioned various sources of biologic and water quality data, largely referencing the AppAqua data, which was collected after the EA was completed.

The project manager for the Town of Boone said that they did not collect any data for planning the project. He also said that USACE oversees the environmental assessment. The project manager noted, however, that it is visually evident that the banks are "falling into the river."

The ASU engineer said ASU is required to complete a "no-rise model." This model must show that raising the recreational fields will not cause flooding to happen upstream. The 
engineer noted that otherwise the ASU Office of Planning, Design and Construction was not involved in any data collection or assessment, but offered assistance with relocating utilities in the project area.

\subsubsection{Monitoring Plan for Evaluating Restoration Efficacy}

USACE made it clear that the Town will be responsible for operation and maintenance once the project is complete. The USACE project planner said that Section 206 projects authorized prior to 2007, which was the case of this project, are not required to have a monitoring or evaluation plan, though establishing a monitoring plan is required for future projects. The engineer noted that USACE will produce an operation and maintenance manual for the Town to follow. However, USACE is not authorized to monitor anything other than vegetation mortality for 1 year.

The project manager for the Town of Boone replied that USACE will "monitor in a limited sense," but otherwise NRC will monitor the restoration's progress. NRC said that it plans to "have monuments to note stream channel change," but otherwise only plan to follow up with invasive species eradication and monitoring plant mortality. NRC anticipates working with the AppAqua research group at ASU to collect follow up biologic and water quality data. Given its role in the project, there is no expectation that the ASU Office of Design and Construction would or should be responsible for carrying out a formal evaluation of the project.

\subsection{Detailed Project Report and Final Environmental Assessment}

The project goals listed in the EA include improving aquatic and riparian habitat, reducing bank failure and preventing greenway loss, and the expected outcome is to restore a degraded system. As already described, the EA includes a diverse array of summarized biologic and water quality data. The EA does note that USACE will provide an operation and maintenance manual to the Town of Boone and will monitor the vegetation for 1 year.

Restoration is being carried out using the Rosgen classification system and Natural Channel Design, which is typical for federal agencies (Lave 2009), yet criticized for over simplifying fluvial systems (Kondolf 2006; Simon et al. 2007; Miller and Kochel 2010). In fact, the EA notes that channel characterization is an inexact science at best, but the project area exhibits various stages of channel evolution and that the incised channel is trying to stabilize itself. However, this would require a significant amount of space and the channel is currently encroaching on the greenway space, "presenting a future challenge for balancing channel needs with recreational needs."

Channel and stream bank stabilization will be attempted by installing anchored slab bundles at the toe of unstable slopes, bank grading and vegetation, and installing bendway weirs. Additionally, clusters of large boulders will be placed to help direct the flow towards the center of the channel and away from the stream banks. An overall site plan is shown in Fig. 3.

According to the EA, stabilizing stream banks is expected to "eliminate the input of failing soils to the stream." Slab bundles are expected to provide bank stability and improve habitat diversity by increasing woody material in the stream and subsequently increasing macroinvertebrate populations. Increasing the vegetation along the stream banks is anticipated to increase habitat diversity for birds, amphibians, reptiles, insects, and small mammals, while providing shade for the stream, thereby lowering water temperature. Installing bendway weirs 


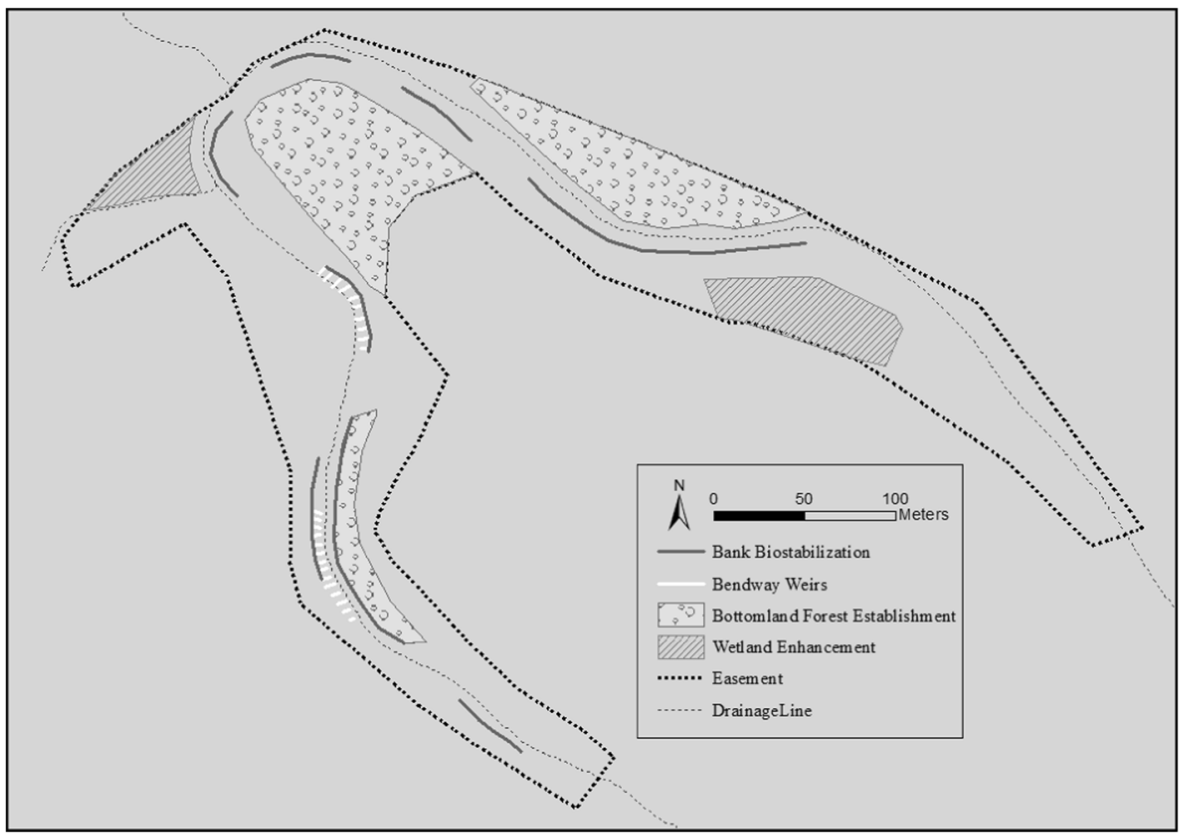

Fig. 3 Overall site plan for the restoration. Primary restoration measures include rehabilitation of wetland areas, invasive species control and re-vegetation, riparian buffer extension and establishment, and bottomland hardwood forest re-vegetation as well as installation of bendway weirs to direct water away from river banks. Source: USACE (2009)

at the two extreme curves in the river is expected to redirect the river current away from the banks, reducing bank undercutting and subsequent bank failure.

Two existing wetlands are being expanded and graded to create permanent ponding areas vegetated with native wetland species and connected to the channel to allow the river into the wetlands. In addition, culverts are being realigned to collect and divert runoff from the recreational fields and parking lots to the wetlands. These wetlands are expected to mitigate stormwater runoff to the river, aid in flood control, reduce sediment loading, and mitigate pollution. Additionally, the wetlands are expected to provide habitat for plants, waterfowl, and other small animals.

Significant riparian vegetation restoration and enhancement is planned. The first step is to eradicate invasive species via spraying. Vegetation, rather than riprap to armor the banks, will be used after grading the banks to a more gradual slope. The vegetation, once established, is expected to anchor the stream bank, while subsequently intercepting stormwater runoff and providing shade for the stream.

Informational signage is being placed to explain the value of maintaining healthy stream systems. River access points and turnouts for viewing the river are expected to re-direct the public away from informal trails along the banks. Directing foot traffic to access points is expected to reduce erosion and decrease negative impacts to riparian vegetation.

\subsection{Biological and Water Quality Review}

Benthic Macroinvertebrate Assessment Table 4 summarizes the NCIBI ratings for five sampling events in the general vicinity of the restoration site. Though not collected specifically 
Table 4 North Carolina Index of Biologic Integrity ratings for macroinvertebrate populations in the general vicinity of the restoration area. Data collected by the North Carolina Department of Environment and Natural Resources July 1993-August 2008. Sampling methods included the Standard Qualitative Method (SQM) and the Ephemeroptera, Plecoptera, and Trichoptera Method (EPT). Source: USACE (2009); NCDENR (2011)

North Carolina biological index ratings for macro invertebrate communities in upper south fork watershed

Data analyzed by the biological assessment branch at NCDENR (1993-2008)

\begin{tabular}{|c|c|c|c|c|c|c|c|}
\hline Stream segment & Site ID & Sample Type & July-1993 & Aug-1998 & Aug-2003 & Nov-2003 & Aug-2008 \\
\hline South fork New River & KB16 & SQM & Fair & Good-Fair & Good-Fair & Fair & Fair \\
\hline $\begin{array}{l}\text { Middle Fork South } \\
\text { Fork New River }\end{array}$ & KB1 & EPT & Excellent & Good & Good-Fair & Poor & Good-Fair \\
\hline $\begin{array}{l}\text { East Fork South } \\
\text { Fork New River }\end{array}$ & KB12 & EPT & Excellent & Good & Good & Good & Good \\
\hline
\end{tabular}

to assess conditions within the project reach, USACE did use these NCDENR data to prepare the EA and project design document.

These data suggest that macroinvertebrate conditions fluctuate, but may be trending downward in these locations within the watershed. The Poor rating on the Middle Fork in 2003, due to a sodium hydroxide spill at the Blowing Rock drinking water treatment plant, contributed to that stream being added to the impaired list, but it has subsequently been removed as its 2008 rating was Good-Fair.

In April of 2013, AppAqua researchers analyzed macroinvertebrate populations using the NCDENR SQM method. The NCIBI rating for mountain regions results in a score of Excellent if the overall BI value is $<4.05$. Values well under 4.05 were found throughout the restoration reach, resulting in BI ratings of Excellent at all three surveyed locations (Table 5).

Fish Community Assessment An electrofishing survey in 2004 was the only biological data collected within the project reach by USACE. More than 25 species were identified, resulting in biological index ratings between 46 and 55, and NCIBI ratings of Good-Fair to Good (USACE 2009). Fish assemblages indicated slight issues related to presence of tolerant

Table 5 North Carolina Index of Biologic Integrity (NCIBI) ratings for benthic communities within riffles of the restoration reach. Data collected and analyzed by AppAqua biologists using North Carolina Department of Environment and Natural Resources standard qualitative method as outlined by Standard Operating Procedures for Benthic Macroinvertebrates (NCDENR 2012). Evenness and Simpson's Index were also calculated as independent measures of biodiversity

NCIBI ratings for macroinvertebrate communities within the restoration reach

AppAqua Macro Invertebrate Sampling 2013

\begin{tabular}{llll}
\hline Restoration reach & Upstream & Midstream & Downstream \\
Total number & 75 & 132 & 80 \\
BI value & 2.87 & 2.29 & 2.59 \\
BI Rating & Excellent & Excellent & Excellent \\
Average evenness & 0.878 & 0.716 & 0.522 \\
Simpson's index/species diversity & 0.867 & 0.843 & 0.896 \\
\hline
\end{tabular}


species and herbivores, the latter indicating lack of shading from riparian forests resulting in excessive solar input into the stream allowing for algae growth, which herbivores feed on.

The AppAqua fish community assessment from 2013 showed similar results to that of the 2004 USACE assessment. A BI value of 52.8 was assigned to the surveyed site and a NCIBI class rating of Good was then applied to the fish index. Large stoneroller populations, Campostoma anomalum, were seen in both the 2004 USACE survey and the 2014 AppAqua survey, and along with tolerant species and only capturing two of the three possible darter species, kept the NCIBI from obtaining an Excellent rating. Table 6 summarizes the data used to make the Good rating.

AppAqua Riverbed Coarse Particle Size Assessment As illustrated in Fig. 4, the distribution of very small size riverbed materials in the riffles of mid and downstream reaches were 2 to 6 times greater than that of the upstream reach, while the upstream reach typically had far more numbers of large size classes. Given that the worst of the bank erosion was found in the downstream reach and the small tributary joined the river there, this may support the presence of an adverse effect from bank erosion on benthic habitat in the downstream reaches of the restoration area.

The median particle class $\left(\mathrm{D}_{50}\right)$ was also greater in the upstream reach when compared to either the mid or downstream reaches (Fig. 4). In the spring of 2013, the $\mathrm{D}_{50}$ for the upstream, midstream and downstream reaches was 16,8 , and $11 \mathrm{~mm}$, respectively. The following spring of 2014 showed a dramatic increase in coarse particle sizes at all reaches. The $\mathrm{D}_{50}$ for the midstream and downstream reaches was $32 \mathrm{~mm}$ while the upstream reach was $64 \mathrm{~mm}$. The increased particle sizes indicated massive transport of sand and small particles out of all of the reaches revealing larger pebbles and rocks over the course of 1 year.

Water Quality Assessment Data from grab samples taken by NCDENR from 1998 to 2003 at AMS station K2100000 were used to develop the EA and are summarized in Table 7. Specific conductivity was variable with a minimum of $20 \mu \mathrm{S} / \mathrm{cm}$ and maximum of $266 \mu \mathrm{S} / \mathrm{cm}$. $\mathrm{pH}$ stays within the normal range of 6 to 9. Turbidity measurements (Nephelometric turbidity

Table 6 North Carolina Index of Biologic Integrity (NCIBI) rating for fish communities sampled during 2013 by AppAqua. The presence of a high number of omnivores and herbivores results in a NCIBI rating of Good for the reach

\begin{tabular}{llll}
\hline NCIBI ratings for fish communities & within the restoration reach & \\
\hline Metric & Quantity & IBI Metric & Score \\
\hline \# of species & 19 & 1 & 5 \\
\# of fish (total) & 387 & 2 & 5 \\
\# of darter sp. & 2 & 3 & 3 \\
\# rockbass, smallmouth, trout sp. & 3 & 4 & 5 \\
\# cyprinids & 9 & 5 & 5 \\
\# of intolerant sp. & 5 & 6 & 5 \\
\% tolerant sp. & 29.2 & 7 & 1 \\
\% omni/herb & 35.4 & 8 & 5 \\
$\%$ insectivores & 58.9 & 9 & 5 \\
\% multiple age groups & 68.4 & 12 & 5 \\
Total $\times 1.2$ (corrected for & & & 52.8 \\
$\quad$ mountain stream) & & & Good \\
Rating & & & \\
\hline
\end{tabular}



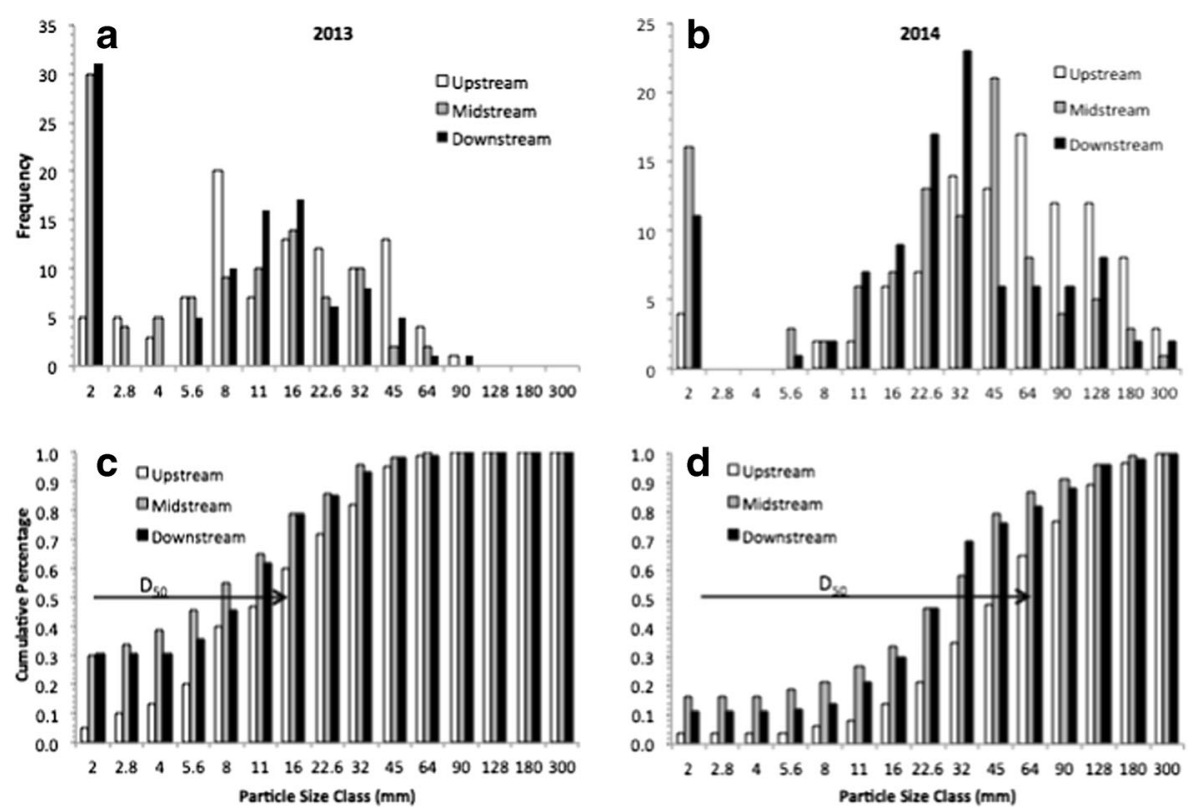

Fig. 42013 and 2014 riverbed coarse particle size distributions. Shown above are the results of 100 riverbed particles randomly selected from ten $10-\mathrm{m}$ transects at each of the upper, mid and lower reaches. Notice that $\sim 30 \%$ of the particles are in the smallest class in the mid and downstream reaches. Cumulative percentages of riverbed coarse particle size distributions are the sum of size class percentages from results from 100 riverbed particles randomly selected from ten 10-m transects at each of the upper, mid, and lower reaches. The $\mathrm{D}_{50}$ for the upstream, midstream and downstream reaches was 16, 8, and $11 \mathrm{~mm}$, respectively, for 2013. Note that in 2014 the $\mathrm{D}_{50}$ for the upstream reach was $64 \mathrm{~mm}$, while midstream and downstream reaches were $32 \mathrm{~mm}$

units, NTU) were well under the North Carolina criteria level (10 NTU) for trout-designated waters, with a very low median of 2 NTU.

In-situ measurements taken by AppAqua sondes at the upstream and downstream monitoring locations are summarized in Table 8 . The high number of samples $(n=28,129)$ provided by the sondes resulted in a highly reliable and accurate database of temperature, $\mathrm{pH}$, and specific conductivity within the restoration reach.

High variability is seen with specific conductance with a minimum of 40 (upstream) to 56 (downstream) and maximums in excess of $2500 \mu \mathrm{S} / \mathrm{cm}$. Median conductivity (approximately $142 \mu \mathrm{S} / \mathrm{cm})$ is comparable to that seen at NCDENR station K2100000 (134 $\mu \mathrm{S} / \mathrm{cm})$. Extreme, short-lived, spikes in conductivity are seen when examining the data over time, and usually occur during winter snowstorms when de-icing salts enter the stream channel and during rain events when stormwater runoff enters the channel (Fig. 5). Maximum temperatures occasionally exceeded the standard for trout designated waters in North Carolina (by as much as $5.2{ }^{\circ} \mathrm{C}$ ); however, the median temperature is well under the evaluation level of $20{ }^{\circ} \mathrm{C}$.

\section{Discussion}

Returning to our initial research questions, this study identified the motivations and expected outcomes for a scheduled restoration project, evaluated whether pre-restoration data support a need for restoration, and identified if any post-project evaluation was planned. 


\subsection{Project Motivation and Expected Outcomes}

Project sponsors along with the documents guiding project implementation, stated that the South Fork restoration project is motivated by a perception that the river suffers from degraded habitat and that visible erosion is causing turbidity and sedimentation problems. Once implemented, the restoration is expected to improve aquatic and riparian habitat by reducing erosion through stream bank stabilization and riparian re-vegetation.

In addition to the ecological goals, project sponsors indicated that the project had recreation-based goals, including ensuring access to the river and protecting the greenway and the ASU athletic fields. In the short term, reducing bank undercutting will likely reduce property loss from the edges of the athletic fields and reduce the risk to the paved greenway trail. Providing definitive access points to the river may reduce the number of paths created through the riparian area to reach the water. Though an improvement to the aquatic habitat through a reduction in sedimentation is stated as the primary motivator, protecting the greenway facilities and athletic fields appears to also be a primary objective. If the channel were left to stabilize on its own, these adjacent facilities would no doubt be in jeopardy.

\subsection{Need for Restoration}

While benthic populations in the general vicinity of the restoration site may be declining, they still reflect overall good quality. Table 5 shows excellent benthic macroinvertebrate populations at the actual restoration site based on 2013 sampling, suggesting that habitat conditions within the project reach are already of high quality.

Fish community assessments also show good overall biologic integrity at the restoration site (Table 6). There is some room for improvement in species diversity, and reducing solar input through increased canopy cover could potentially help balance the trophic-level representatives among the fish populations; however, this could take many years to see results. Furthermore, eradicating invasive plant species will remove much of the existing riparian buffer and will likely result in less shade and increased temperatures until the new vegetation matures.

Overall, in-stream water quality is good (Tables 7 and 8), however, specific conductivity can surge during winter storms at the restoration site (Fig. 5). Re-establishing wetlands may help mitigate local stormwater runoff to the stream and provide a buffer from some localized pollutants, but it is not likely to clean up pollutants generated from upstream areas.

While reducing turbidity and sedimentation via bank stabilization are stated as a primary motivation for this project, Table 7 shows that turbidity levels are well under the 10 NTU

Table 7 Water quality data from the North Carolina Department of Environment and Natural Resources Ambient Monitoring System Station K2100000 used for developing the restoration environmental assessment. Parameters reported in the Environmental Assessment included specific conductance, $\mathrm{pH}$, and turbidity. Source: USACE (2009)

Water quality data from NCDENR AMS monitoring station K2100000 (1998-2003)

\begin{tabular}{llllll}
\hline Parameter & $\mathrm{N}$ & Criteria Exceedance Level & Minimum & Median & Maximum \\
\hline Specific conductance $(\mu \mathrm{S} / \mathrm{cm})$ & 44 & $\mathrm{n} / \mathrm{a}$ & 20 & 134 & 266 \\
$\mathrm{pH}$ & 45 & $<6,>9$ & 5.9 & 7 & 7.6 \\
Turbidity (NTU) & 53 & $>10$ (Trout Designated) & 1 & 2 & 22 \\
\hline
\end{tabular}


Table 8 Water quality parameters measured via In-Situ 9500 water quality monitoring sondes within the restoration reach from October 2013 to April 2014

Water quality data from AppAqua monitoring stations (October 23, 2013-August 15, 2014)

\begin{tabular}{|c|c|c|c|c|c|c|c|c|c|}
\hline \multirow[t]{2}{*}{ Parameter } & \multirow{2}{*}{$\begin{array}{l}\text { Criteria } \\
\text { exceedance } \\
\text { level }\end{array}$} & \multicolumn{2}{|l|}{$\mathrm{N}$} & \multicolumn{2}{|c|}{ Minimum } & \multicolumn{2}{|l|}{ Median } & \multicolumn{2}{|c|}{ Maximum } \\
\hline & & $\begin{array}{l}\text { Up } \\
\text { stream }\end{array}$ & $\begin{array}{l}\text { Down } \\
\text { stream }\end{array}$ & $\begin{array}{l}\text { Up } \\
\text { stream }\end{array}$ & $\begin{array}{l}\text { Down } \\
\text { stream }\end{array}$ & $\begin{array}{l}\text { Up } \\
\text { stream }\end{array}$ & $\begin{array}{l}\text { Down } \\
\text { stream }\end{array}$ & $\begin{array}{l}\text { Up } \\
\text { stream }\end{array}$ & $\begin{array}{l}\text { Down } \\
\text { stream }\end{array}$ \\
\hline $\begin{array}{l}\text { Specific } \\
\text { Conductance } \\
(\mu \mathrm{S} / \mathrm{cm})\end{array}$ & $\mathrm{n} / \mathrm{a}$ & 28129 & 28129 & 40 & 56 & 143 & 140 & 2606 & 2621 \\
\hline $\mathrm{pH}$ & $<6,>9$ & 28129 & 28129 & 5.5 & 5.3 & 6.9 & 6.7 & 7.9 & 7.7 \\
\hline Temperature $\left({ }^{\circ} \mathrm{C}\right)$ & $\begin{array}{r}>20{ }^{\circ} \mathrm{C} \text { Trout } \\
\text { Designated }\end{array}$ & 28129 & 28129 & 0 & 0 & 10.5 & 10.6 & 23.7 & 25.2 \\
\hline
\end{tabular}

standard for trout streams, and particle size data (Fig. 4) reveal that there has been substantial improvement in riverbed habitat quality, possibly from the 2013 record rainfalls and increased summer flows removing the fine particulates and sand from the reach. Interstitial spaces between the benthic substrate particles are actually the "habitat" that house the eggs and larvae of many aquatic animals. The small particles that enter the river from bank erosion can cause increased coarse riverbed particle embeddedness. However, the data show that there was a significant reduction in the amount of small particles, and therefore, an increased quality of the benthic habitat for meiofauna such as macroinvertebrates as well as eggs and larvae of fish and amphibians. Because we only had 2 years of data available for this analysis, and the second year was concurrent with record setting rainfall, we cannot say conclusively what is responsible (natural variation or the increased flows) but we can show that the benthic substrate was improved in 2014. Because the benthic macroinvertebrates were already excellent, the improved riverbed should continue to support as good or better community assemblages.

This study highlights the disparity between perceptions of visible erosion and an automatic assumption that this equates to a sediment problem. Erosion, of course, is a normal physical

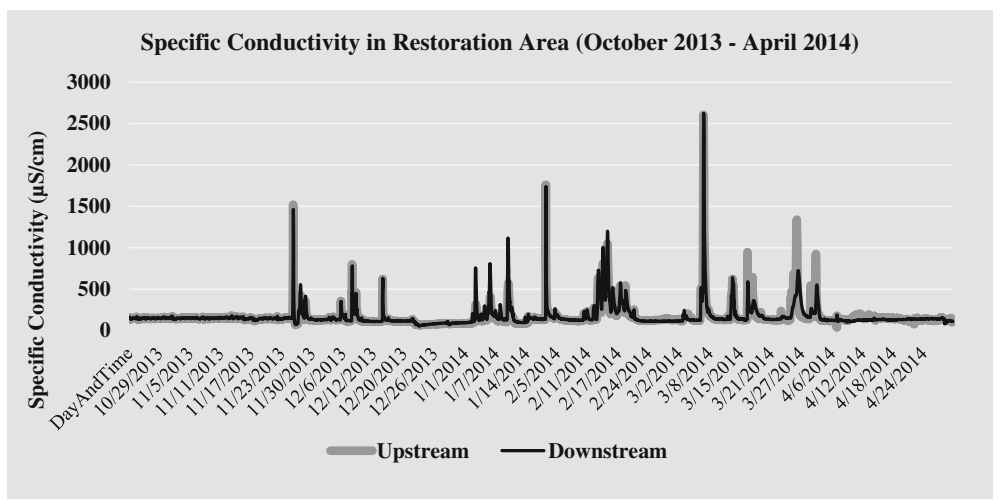

Fig. 5 Specific conductivity $(\mu \mathrm{S} / \mathrm{cm})$ as measured at AppAqua water quality monitoring stations. One sonde is located at the upstream end of the project (lighter line), and another is located at the downstream end (darker line). Significant spikes in conductivity are seen during winter storms and rain events. Typically the sondes have similar measurements, however, during precipitation events the measurements between sondes may deviate from each other. This indicates that runoff between the sondes could be influencing water quality in the reach 
process for a river system. In fact, Florsheim et al. (2008) argue that the focus on reducing or halting erosion is a flawed management approach and that erosion needs to be accepted as a desirable trait for many streams. Relevant to our study, there are two facets to the erosion issue. First, is that runoff-driven sediment is common in a steep-gradient mountain stream and onstream bank stabilization will not affect upstream runoff. Second, and perhaps most relevant, available data show that no turbidity or sediment problems exist under baseflow conditions at the study location.

Stabilizing stream banks could help reduce bank loss at the restoration site during rain events, but it is unlikely that this will decrease turbidity during storm flow because runoff-driven sediment transport will continue to occur from upstream sources. As development continues upstream, runoff may overwhelm erosionreducing efforts. Furthermore, the restoration itself will cause a temporary absence of mature vegetation in the riparian zone and this could lead to increased susceptibility to severe bank erosion during storms.

\subsection{Post-project Monitoring and Evaluation}

The project sponsors do not have an official monitoring plan in place for this restoration. The data used to justify the project and develop the environmental assessment and project plan present temporal and spatial issues that may preclude conducting valid post-project assessments. For example, benthic macroinvertebrate assemblages represent highly localized conditions, and although the sampling stations used to provide data for the EA are in the general vicinity of the site, the usefulness of these data as habitat indicators for evaluating restoration measures is reduced by the geographic disconnect of the sampling sites from the project reach. These data also present a temporal disconnect as the surveys used in the EA were from 2003 and 2008 and the project did not begin until 2014.

The USACE fish survey is the only habitat data that a project sponsor collected in the actual restoration area, and would be a good source of data to evaluate the efficacy of restoration implementation. However, there is a temporal discrepancy between when the fish data were collected (2004), when the EA was completed (2009), and project implementation (2014). This disconnect reduces the ability to properly assess the effect of restoration on the fish community based on the data provided by the EA.

Echoing existing research showing a disconnect between those who research restoration and those who implement restoration (Rhoads et al. 1999; Wohl et al. 2005; Wheaton et al. 2006; Cockerill and Anderson 2014), this study finds that the data most appropriate for post-project evaluation was not collected by any of the project sponsors, but by the AppAqua research group. The AppAqua team, however, is not directly affiliated with the restoration project in the same way as the project sponsors. The NRC is interested in understanding the effects of restoration measures and hope to work with AppAqua researchers to continue to collect data within the restoration reach. Given the lack of funding and no requirements, any continued monitoring is only likely because AppAqua team members include this as community based research in various courses. Assuming the data collection continues through AppAqua, post-implementation evaluation of the restoration is definitely feasible. Whether these results would be integrated into any future decisions on the New River is open to debate. 


\section{Conclusions}

Our study highlights issues relevant to data used to justify a restoration project and the need for appropriate baseline data to determine actual conditions. Clearly the data indicated that this reach of the New River needed very little, if any, assistance. Consistent with findings in the literature, this project design was based on previous experience and existing agency reports (Hassett et al. 2007; Bernhardt et al. 2007; Sudduth et al. 2007) rather than on site-specific data gathered explicitly for the effort. This begs the question of whether other streams have likewise been restored unnecessarily because of false assumptions and poor pre-condition data.

Collecting appropriate pre-restoration data, for example measuring the most effective parameters at the appropriate scale of measurement, and accounting for representing multiscale (e.g., watershed) processes is key to accurately understanding existing problems (Moerecki and Lamberti 2003; Smith and Prestgaar 2005; Whol et al. 2005). Ramifications of not collecting optimal pre-restoration data can be significant and can lead to diminished success or project failure (Kondolf et al. 2001; Moerke and Lamberti 2003; Smith and Prestegaard 2005). The South Fork New River restoration project reflects a lack of preproject data collected within the actual restoration project reach, and within a relevant time period. Although project sponsors want to improve habitat quality and perceive that sedimentation is killing benthic populations, the sponsors did not collect any data within the reach that would justify this conclusion. Additionally, the longevity of the planning and design process from inception (1998) to actual implementation (2014) resulted in decreased baseline data quality issues. The geographic and temporal disconnects in data used to develop the EA, consequently, reduce the overall ability to justify restoration or evaluate the project postimplementation.

This study highlights disconnects among perceptions of stream conditions, restoration project goals, and data used to design and implement a restoration project. While project sponsors do perceive that the New River restoration project is data-driven, this assessment suggests otherwise. The visible erosion and subsequent assumptions about aquatic habitat quality seemed to have prompted this project initially and provided impetus for the project to continue. Based on pre-existing conditions, however, the primary outcomes from this restoration project will most likely be athletic field and greenway protection as well as improved access to the river.

Protecting the built environment and public space is a legitimate use of public funds as public welfare is enhanced. Justifying these projects based on ecological improvement, however, is potentially detrimental for management activities and funding acquirement for projects that could have a positive impact on habitat quality. The potential for improving aquatic habitat is diminished most obviously because conditions are already quite good. Over a longer temporal scale, this project may be limited in the ability to improve conditions or prevent degradation because of concentrated anthropogenic activities (e.g., deforestation and increasing impervious surfaces) occurring upstream within the watershed as well as adjacent to the restored reach. Unless measures are taken to reduce upstream impacts, this restoration project is unlikely to have much effect on ecological conditions at this site and may not even succeed in protecting the localized built environment.

Acknowledgments The authors would like to thank the Cratis D. Williams Graduate School Graduate Research and Mentoring (GRAM) Program, the Research Institute for Energy, Environment and Economics, the College of Arts and Sciences, and the Department of Geography and Planning at Appalachian State University for their 
financial support of this research. In addition, we would like to thank the 2013-2014 Ecotoxicology and Invertebrate Zoology course students at Appalachian State University for collecting the AppAqua biological assemblage data presented in this study.

\section{References}

Alexander GG, Allan JD (2007) Ecological success in stream restoration: case studies from the mid-western United States. Environ Manag 40:245-255

Bernhardt ES, Palmer MA (2011) River restoration: the fuzzy logic of repairing reaches to reverse catchment scale degradation. Ecol Appl 21(6):1926-1931

Bernhardt ES, Palmer MA, Allan JD, Alexander GG, Barnas K, Brooks S, Carr J, Clayton S, Dahm C, FollstadShah J, Galat D, Gloss S, Goodwin P, Hart D, Hassett B, Jenkinson R, Katz S, Kondolf GM, Lake PS, Lave R, Meyer JL, O’Donnell TK, Pagano L, Powell B, Sudduth EB (2005) Synthesizing U.S. river restoration efforts. Science 308:636-637

Bernhardt ES, Sudduth EB, Palmer MA, Allan JD, Meyer JL, Alexander GG, Follastad-Shah J, Hassett B, Jenkinson R, Lave R, Rumps J, Pagano L (2007) Restoring rivers one reach at a time: results from a survey of U.S. river restoration practitioners. Restor Ecol 15(3):482-493

Cabin R (2007) Science-driven restoration: a square grid on a round Earth? Restor Ecol 15(1):1-7

Christian-Smith J, Merenlender AM (2010) The disconnect between restoration goals and practices: a case study of watershed restoration in the Russian River Basin, California. Restor Ecol 18(1):95-102

Cockerill K, Anderson WP (2014) Creating false images: stream restoration in an urban setting. J Am Water Resour Assoc 50(2):468-482

Downs PW, Singer MS, Orr BK, Diggory ZE, Church TC (2011) Restoring ecological integrity in highly regulated rivers: the role of baseline data and analytical references. Environ Manag 48:847-864

Dufour S, Piegay H (2009) From the myth of a lost paradise to targeted river restoration: forget natural references and focus on human benefits. River Res Appl 25:568-581

Florsheim JL, Mount JF, Chin A (2008) Bank erosion as a desirable attribute of rivers. Bioscience 58(6):519-529

Hassett BA, Palmer MA, Bernhardt ES (2007) Evaluating stream restoration in the Chesapeake Bay watershed through practitioner interviews. Restor Ecol 15(3):563-572

Institutional Research, Assessment, and Planning (IRAP) (2013) Appalachian State University fact book. http:// irap.appstate.edu/fact-book/fast-facts. Accessed 4 July 2014

Kondolf GM (2006) River restoration and meanders. Ecol Soc 11(2):42

Kondolf GM, Smeltzer MW, Railsback SF (2001) Design and performance of a channel reconstruction project in a coastal California gravel-bed stream. Environ Manag 28(6):761-776

Kondolf GM, Anderson S, Lave R, Pagano L, Merenlender A, Bernhardt ES (2007) Two decades of river restoration in California: what can we learn? Restor Ecol 15(3):516-523

Lave R (2009) The controversy over natural channel design: substantive explanations and potential avenues for resolution. J Am Water Resour Assoc 45(6):1519-1532

Miller JR, Kochel RC (2010) Assessment of channel dynamics, in-stream structures and post-project channel adjustments in North Carolina and its implications to effective stream restoration. Environ Earth Sci 59(8): $1681-1692$

Moerke AH, Lamberti GA (2003) Responses in fish community structure to restoration of two Indiana streams. N Am J Fish Manag 23:748-759

Niezgoda SL, Johnson PA (2005) Improving the urban stream restoration effort: identifying critical form and processes relationships. Environ Manag 35(5):579-592

North Carolina Department of Environment and Natural Resources (2011) New River basinwide water quality plan. http://portal.ncdenr.org/web/wq/ps/bpu/basin/new/2011. Accessed 28 May 2014

North Carolina Department of Environment and Natural Resources (2012) Standard operating procedures for benthic macroinvertebrates. http://portal.ncdenr.org/c/document library/get file?uuid=f3cfa483-16de-4c1895b7-93684c1b64aa\&groupId=38364. Accessed 25 June 2014

North Carolina Department of Environment and Natural Resources (2013) Standard operating procedure biological monitoring stream fish community assessment program. http://portal.ncdenr.org/c/document library/get_file?p_1_id=1169848\&folderId=125626\&name=DLFE-78577.pdf. Accessed 25 June 2014

O’Donnel TK, Galat DL (2008) Evaluating success criteria and project monitoring in river enhancement within an adaptive management framework. Environ Manag 41(1):90-105

Palmer MA, Allan JD (2006) Restoring rivers. National Academy of Science, Issues in Science and Technology, winter 2006 
Palmer MA, Mennenger HL, Bernhardt ES (2010) River restoration, habitat heterogeneity, and biodiversity: a failure of theory or practice? Freshw Biol 55(1):205-222

Rhoads BL, Wilson D, Urban M, Herricks EE (1999) Interaction between scientists and nonscientists in community-based watershed management: emergence of the concept of stream naturalization. Environ Manag 24(3):297-308

Shields FD, Cooper CM, Knight SS, Moore MT (2003) Stream corridor restoration research: a long and winding road. Ecol Eng 20:441-454

Simon A, Doyle M, Kondolf GM, Shields FD Jr, Rhoads B, McPhillips M (2007) Critical evaluation of how the Rosgen classification method and associated "Natural Channel Design" methods fail to integrate and quantify fluvial processes and channel response. J Am Water Res Assoc 43(5):1117-1131

Smith SM, Prestegaard KL (2005) Hydraulic performance of a morphology-based stream channel design. Water Resour Res 41, W11413

Sudduth EB, Meyer JL, Bernhardt ES (2007) Stream restoration practices in the southeastern United States. Restor Ecol 15(3):573-583

U.S. Army Corp of Engineers (2009) Detailed project report and final environmental assessment Watauga Section 206 aquatic ecosystem restoration project Town of Boone, North Carolina. U.S Army Engineer District, Huntington Corps of Engineers. Huntington, West Virginia

U.S. Census Bureau (2010) State and county quickfacts: Watauga, County, North Carolina. http://quickfacts. census.gov. Accessed 1 July 2014

Violin CR, Cada P, Sudduth EB, Hassett BA, Penrose DL, Bernhardt ES (2011) Effects of urbanization and urban stream restoration on the physical and biological structure of stream ecosystems. Ecol Appl 21(6):19321949

Water Resources Development Act, Public Law 104-303, §206, 2 U.S.C. 651 (1996)

Wheaton JM, Darby SE, Sear DA, Milne JA (2006) Does scientific conjecture accurately describe restoration practice? Insight from an international river restoration survey. Area 38(2):128-142

Woelfle-Erskine C, Wilcox AC, Moore JN (2012) Combining historical and process perspectives to infer ranges of geomorphic variability and inform river restoration in a wandering gravel-bed river. Earth Surf Process Landf 37:1302-1312

Wohl E, Angermeier PL, Bledsoe B, Kondolf GM, MacDonnell L, Merritt DM, Palmer MA, Poff NL, Tarboton D (2005) River restoration. Water Resour Res 41, W10301

Wolman MG (1954) A method of sampling coarse riverbed material. Trans Am Geophys Union 35(6):951-956 